УДК 036.4.082

(C) 2016

Флока Л. В., асистент кафедри товарознавства продовольчих товарів

(науковий керівник - доктор сільськогосподарських наук В. М. Волощук)

Полтавський університет економіки і торгівлі, Інститут свинарства і АПВ НААН України

\title{
ВПЛИВ РІВНЯ ГОДІВЛІ СВИНЕЙ ЧЕРВОНОЇ БІЛОПОЯСОЇ ПОРОДИ НА ІНТЕР'СРНІ ПОКАЗНИКИ
}

\section{Рецензент - доктор сільськогосподарських наук Г. О. Бірта}

Наведено результати досліджень впливу рівня годівлі свиней червоної білопоясої породи на інтер'єрні показники. Важливим етапом селекційної роботи у свинарстві є визначення та розробка критеріїв прогнозування продуктивності тварини у ранньому віці за інтер'єрними ознаками. Це прискорює процес оцін$\kappa и$ племінної иінності тварин та удосконалює племінну роботу у стаді. Використання інтер'єрних показників тварин у племінній роботі зі стадом вказує на те, щуо в сучасних умовах промислового свинарства зростають вимоги щуодо генетичної та біологічної якості свиней, пристосованості їх до умов утримання та годівлі.

Ключові слова: кров, сироватка крові, гемоглобін, еритроцити, глобулін, альбумін, білки, ферменти.

Постановка проблеми. Ефективність галузі свинарства зумовлена використанням високопродуктивних тварин різних порід і типів у разі створення оптимальних умов відгодівлі і утримання для реалізації генетичного потенціалу. Продуктивність свиней оцінюють по відтворювальній здатності маток і кнурів, відгодівельній і м'ясній продуктивності молодняка. Поряд із візуальною оцінкою екстер'єру, промірами та масою свиней їх конституцію можна вивчати значно точнішими методами, які дають змогу дослідити структуру та функції органів, систем органів, тканин і різних залоз, які суттєво впливають на тип конституції, характер продуктивності; проаналізувати більш глибокі біологічні процеси, що відбуваються в організмі свиней за різних факторів впливу умов зовнішнього середовища $[3,8]$.

Інтер'єр - це сукупність внутрішніх фізіологічних, анатомо-гістологічних і біохімічних властивостей організму щодо його конституції і направлення продуктивності.

Без знання інтер'єру тварини не можна вести поглиблену племінну роботу, направлену на вдосконалення продуктивних якостей [7].

Інтер'єрний спосіб вивчення та оцінки якостей свиней повинен бути пов'язаний з екстер'єрним. Лише у цьому випадку можна розраховувати на якісні результати. Завданням інтер'єрного дослідження є глибше вивчення конституції тварин головним чином для того, щоб вивчити їх племінну цінність, правильно провести відбір і знайти найкращі прийоми їх вирощування й експлуатації [4].

Для вивчення інтер'єру застосовують різні методи: анатомо-гістологічний, фізіологічний, хімічний, гематологічний, рентгеноскопічний, ендокринологічний. Деякі дослідження проводять прижиттєво, а інші пов'язані з необхідністю забою свиней. За прижиттєвого дослідження важливе значення має кров, яка відбиває найважливіші життєві прояви організму і дає можливість визначити конституціональні особливості, фізіологічний стан та характер продуктивності тварин. У складі крові вивчають іiі формені елементи, вміст сухих речовин, лужний резерв, буферність, гемоглобін, білок, цукор; кальцій, фосфор, мікроелементи, вітаміни, антибіотики [1].

Аналіз основних досліджень i публікацій, у яких започатковано розв'язання проблеми. Кров - рідка сполучна тканина організму тварин, що виконує важливі функції в забезпеченні його життедіяльності.

Разом 3 лімфою і тканинною рідиною кров $\epsilon$ внутрішнім середовищем організму. Вона виконує в організмі багато важливих функцій. Основною 3 них $є$ перенесення газів, тобто кисню, від органів дихання до тканин і вуглекислого газу від тканин до органів дихання. Здатність крові зв'язувати $\mathrm{O}_{2}$ i віддавати його тканинам зумовлена наявністю в ній пігментів (гемоглобіну, хлорокруорину, гемеритрину) [6].

Крім того кров переносить поживні речовини від шлунково-кишкового тракту до тканин; вимиває кінцеві продукти обміну речовин із тканин і переносить їх до органів виділення (нирки, шкіра); переносить біологічно активні речовини (гормони, вітаміни, ферменти тощо); бере участь у терморегуляції; захищає організм від мікроорганізмів і чужорідних тіл [2].

Мета досліджень та методика їх проведення. Ми поставили за мету дослідити вплив рівня го- 


\section{СІЛЬСЬКЕ ГОСПОДАРСТВО. ТВАРИННИЦТВО}

дівлі на інтер'єрні показники свиней червоної білопоясої породи, а саме кількість еритроцитів в 1 мм $^{3}$ крові, вміст гемоглобіну, вміст білка i білкових фракцій, активність ферментів та вміст кальцію та неорганічного фосфору у сироватці крові свинок у випадку різних умов годівлі.

Для виконання запланованих досліджень тварин було розділено на три групи: I група - годівля за нормою; II група - годівля на $25 \%$ вище норми; III група - годівля на 25 \% нижче норми.

Тварин I групи годували за існуючими нормами енергетичного і протеїнового живлення. Тварини II піддослідної групи одержували цей же комбікорм на 25 \% більше норми, крім того протеїнова частина корму збільшувалась за рахунок сухого обрату (100 г сухого збираного молока на добу). Тварини III піддослідної групи одержували добову даванку на 25 \% нижче існуючої норми.

Раціони для свинок усіх груп були однаковими як за набором, так і за співвідношенням кормів. Концентровані корми становили 86,4 \% від загальної поживності раціону, грубі, соковиті та зелені - 13,6 \%. У середньому на 1 корм. од. корму припадало: перетравного протеїну - 115 г, кальцію - 6,4 г і фосфору - 4,4 г. Догляд та утримання свинок були аналогічними. Годували свинок двічі на добу за вільного доступу до води.

Для гематологічних досліджень було взято кров піддослідних тварин до ранкової годівлі із хвоста. Визначали вміст гемоглобіну гемометром Салі, кількість еритроцитів шляхом підрахунку в лічильній камері Горяєва, кількість загального білка за методом К'єдьдаля і його фракцій методом висолювання, описаним О. В. Травіною (1955). Активність каталази визначали за А. Н. Бахом і С. Р. Зубковою, пероксидази - за П. В. Симаковим [1, 5].
Результати досліджень. За період вирощування від 2- до 8-місячного віку істотної різниці між показниками в рості і розвитку свинок не встановлено. За практично однакової постановочної маси відставання свинок у випадку зниженої інтенсивності годівлі (на 25 \% нижче норми) від перших двох виявлялось уже в 4-місячному віці і зберігалось до кінця вирощування.

Неоднаковий середньодобовий приріст живої маси у молодняка порівнюваних груп тварин пояснюється очевидно різною інтенсивністю обмінних процесів, що протікають в їх організмі. Це до деякої міри підтверджується i даними складу крові (табл. 1).

Дані досліджень свідчать, що найвищі показники кількості еритроцитів та вмісту гемоглобіну були у крові свиней за інтенсивної відгодівлі (на $25 \%$ вище норми), не набагато нижчі - у свиней за нормальної відгодівлі, а найнижчі - у тварин у випадку зниженої годівлі (на 25 \% нижче норми).

Що ж до зміни цих показників з віком тварин, то у свинок усіх піддослідних груп вони зростають до восьми місяців. Проте їх зростання відбувалося по-різному. Так, якщо у свинок у випадку інтенсивної відгодівлі за досліджуваний період кількість еритроцитів збільшилась на 17,93\%, вміст гемоглобіну - на 10,08 \%, то у свинок у разі годівлі за нормою - відповідно на 18,8 та $12,82 \%$, а у свинок у випадку зниженої годівлі лише на 17,02 та $10 \%$ відповідно.

Дещо по-іншому змінюється вміст одного 3 головних складових частин крові - білка (табл. $2,3)$. Таке збільшення відбувається переважно за рахунок глобулінів, вміст яких за період вирощування у свинок за нормованої відгодівлі підвищився на 0,98 \%, за інтенсивної відгодівлі - на 1,04 і у випадку зниженої годівлі - на 0,70 \%.

\section{1. Кількість еритроцитів та концентрація гемоглобіну в крові свинок різних порід (М士m)}

\begin{tabular}{|c|c|c|c|c|c|c|}
\hline \multirow[b]{2}{*}{ Вік } & \multicolumn{2}{|c|}{ За нормою } & \multicolumn{2}{|c|}{ Вище норми на 25 \% } & \multicolumn{2}{|c|}{ Нижче норми на 25 \% } \\
\hline & $\begin{array}{c}\text { кількість } \\
\text { еритроцитів в } \\
1 \text { мм³ }^{3} \text { крові, млн }\end{array}$ & $\begin{array}{c}\text { вміст } \\
\text { гемоглобіну, } \\
\%\end{array}$ & $\begin{array}{c}\text { кількість } \\
\text { еритроцитів в } \\
1 \text { мм }{ }^{3} \text { крові, } \\
\text { млн }\end{array}$ & $\begin{array}{c}\text { вміст } \\
\text { гемоглобіну, } \\
\%\end{array}$ & $\begin{array}{c}\text { кількість } \\
\text { еритроцитів в } \\
1 \text { мм }{ }^{3} \text { крові, } \\
\text { млн }\end{array}$ & $\begin{array}{c}\text { вміст } \\
\text { гемогло- } \\
\text { біну, \% }\end{array}$ \\
\hline 2 мic. & 0,02 & & 5,17 & 10 & $5,02 \pm 0,04$ & 9,9 \\
\hline 4 міс. & $5,59 \pm 0,12$ & $11,1 \pm 0,15$ & $5,62 \pm 0,18$ & $11,4 \pm 0,15$ & $5,45 \pm 0,05$ & $10,7 \pm 0,04$ \\
\hline 6 мiс. & $6,18 \pm 0,05$ & $12,0 \pm 0,09$ & $6,22 \pm 0,02$ & $12,2 \pm 0,09$ & $5,92 \pm 0,11$ & $11,2 \pm 0,09$ \\
\hline 8 міс. & $6,27 \pm 0,06$ & $11,7 \pm 0,14$ & $6,30 \pm 0,04$ & $11,9 \pm 0,1$ & $6,05 \pm 0,08$ & $11,0 \pm 0,15$ \\
\hline
\end{tabular}


СІЛЬСЬКЕ ГОСПОДАРСТВО. ТВАРИННИЦТВО

\section{2. Вміст білка та білкових фракцій у сироватці крові свинок у випадку різних умов годівлі, \%} $(M \pm m)$

\begin{tabular}{|c|c|c|c|c|c|c|}
\hline \multirow{2}{*}{ Вік } & \multicolumn{3}{|c|}{ На 25 \% вище норми } & \multicolumn{3}{c|}{ На 25 \% нижче норми } \\
\cline { 2 - 7 } & білок & альбуміни & глобуліни & білок & альбуміни & глобуліни \\
\hline 2 міс. & $6,40 \pm 0,07$ & $3,12 \pm 0,05$ & $3,28 \pm 0,04$ & $5,37 \pm 0,19$ & $2,97 \pm 0,05$ & $2,90 \pm 0,15$ \\
\hline 4 міс. & $6,75 \pm 0,09$ & $3,12 \pm 0,06$ & $3,63 \pm 0,06$ & $6,25 \pm 0,06$ & $3,07 \pm 0,14$ & $3,18 \pm 0,02$ \\
\hline 6 міс. & $7,02 \pm 0,08$ & $3,07 \pm 0,05$ & $3,95 \pm 0,05$ & $6,45 \pm 0,05$ & $3,12 \pm 0,07$ & $3,33 \pm 0,05$ \\
\hline 8 міс. & $7,21 \pm 0,10$ & $3,04 \pm 0,06$ & $3,17 \pm 0,05$ & $6,57 \pm 0,08$ & $3,12 \pm 0,02$ & $3,45 \pm 0,05$ \\
\hline
\end{tabular}

3. Вміст білка та білкових фракцій у сироватці крові свинок у разі годівлі за нормою, \% (М $\pm m)$

\begin{tabular}{|c|c|c|c|}
\hline \multirow{2}{*}{ Вік } & \multicolumn{3}{|c|}{ За нормою } \\
\cline { 2 - 4 } & білок & альбуміни & глобуліни \\
\hline 2 міс. & $6,14 \pm 0,09$ & $3,10 \pm 0,05$ & $3,04 \pm 0,04$ \\
\hline м міс. & $6,51 \pm 0,11$ & $3,08 \pm 0,07$ & $3,43 \pm 0,08$ \\
\hline 6 міс. & $6,85 \pm 0,09$ & $3,15 \pm 0,07$ & $3,60 \pm 0,03$ \\
\hline 8 міс. & $7,00 \pm 0,08$ & $3,09 \pm 0,05$ & $3,81 \pm 0,13$ \\
\hline
\end{tabular}

Варто зазначити, що глобулінова фракція переважає над альбуміновою у молодняка в разі нормованої та зниженої годівлі з 4- до 8-місячного віку, а у свинок у випадку інтенсивної відгодівлі - ще й у 2-місячному віці. Тому відношення альбумінів до глобулінів у сироватці крові свиней майже завжди було нижче одиниці.

3 віком тварин білковий коефіцієнт крові свинок змінюється неоднаково. Так, відношення альбумінів до глобулінів у молодняка всіх піддослідних груп знижується.

Вміст альбумінів у крові свинок усіх трьох груп протягом періоду вирощування залишався практично на одному рівні, але питома вага їх у загальному білку постійно знижувалась.

Нормальне протікання обмінних процесів в організмі тварин тісно пов'язане з певним вмістом у крові таких мінеральних речовин, як кальцій і фосфор (табл. 4).

Дані таблиці свідчать, що у сироватці крові піддослідних груп свинок вміст кальцію постійно знижується до кінця вирощування на 1,0-1,7, а фосфору - на 2,8-3,1\%.

У сироватці крові молодняка за інтенсивної відгодівлі вміст кальцію та фосфору був найвищим, дещо меншим він був у свиней за нормальної годівлі свиней і найменшим - у разі годівлі на $25 \%$ нижче норми.

Про скороспілість та рівень обмінних процесів в організмі свиней можна також судити за активністю ферментів крові (табл. 5).

Результати досліджень свідчать про те, що в більшості вікових періодів активність каталази і пероксидази була вірогідно вищою у більш скороспілих свинок за інтенсивного рівня годівлі. Найнижча ж активність ферментів крові спостерігалась у молодняка у випадку зниженого рівня годівлі на $25 \%(\mathrm{P}>0,95-0,99)$.

Активність каталази крові свиней незалежно від їх породи зростає до 8-місячного віку, а пероксидази - до 6 місяців з наступним спадом до 8 місяців. За період з 2- до 8-місячного віку активність каталази крові молодняка підвищувалась у 1,7-1,9 рази, а пероксидази, 3 2- до 6місячного віку - у 2,2-2,6 рази. Варто зазначити, що інтенсивність наростання активності ферментів у різні вікові періоди була неоднаковою.

\section{4. Вміст кальцію та неорганічного фосфору в сироватці крові свинок у випадку різних умов годівлі, \% (M士m)}

\begin{tabular}{|c|c|c|c|c|c|c|}
\hline \multirow{2}{*}{ Вік } & \multicolumn{5}{|c|}{ Група } \\
\cline { 2 - 7 } & \multicolumn{2}{|c|}{ за нормою } & на 25 \% вище норми & \multicolumn{2}{c|}{ на 25 \% нижче норми } \\
\cline { 2 - 7 } & $\mathrm{Ca}$ & $\mathrm{P}$ & $\mathrm{Ca}$ & $\mathrm{Ca}$ & $\mathrm{P}$ & Са \\
\hline 2 міс. & $12,0 \pm 0,09$ & $8,0 \pm 0,11$ & $12,4 \pm 0,09$ & $8,4 \pm 0,15$ & $11,5+0,11$ & $7,7+0,10$ \\
\hline 4 міс. & $11,6 \pm 0,15$ & $7,6 \pm 0,15$ & $12,2 \pm 0,09$ & $7,9 \pm 0,03$ & $11,0 \pm 0,15$ & $7,3 \pm 0,18$ \\
\hline 6 міс. & $11,3 \pm 0,16$ & $6,2 \pm 0,09$ & $11,8 \pm 0,11$ & $6,5+0,04$ & $10,6 \pm 0,15$ & $5,8 \pm 0,11$ \\
\hline 8 міс. & $11,0 \pm 0,11$ & $5,7+0,12$ & $11,5 \pm 0,12$ & $5,9 \pm 0,09$ & $10,4 \pm 0,11$ & $5,4 \pm 0,12$ \\
\hline 10 міс. & $10,6+0,09$ & $5,2 \pm 0,09$ & $11,0 \pm 0,15$ & $5,3 \pm 0,09$ & $9,8 \pm 0,09$ & $4,8 \pm 0,15$ \\
\hline
\end{tabular}


СІЛЬСЬКЕ ГОСПОДАРСТВО. ТВАРИННИЦТВО

5. Активність ферментів крові свинок у випадку різних умов годівлі (М士m)

\begin{tabular}{|l|c|c|c|c|c|c|}
\hline \multirow{2}{*}{ Вік } & \multicolumn{2}{|c|}{ За нормою } & \multicolumn{2}{c|}{ На 25 \% вище норми } & \multicolumn{2}{c|}{ На 25 \% нижче норми } \\
\cline { 2 - 7 } & $\begin{array}{c}\text { каталаза, од. } \\
\mathrm{H}_{2} \mathrm{O}_{2}\end{array}$ & $\begin{array}{c}\text { пероксидаза, } \\
\text { сек. }\end{array}$ & $\begin{array}{c}\text { каталаза, од. } \\
\mathrm{H}_{2} \mathrm{O}_{2}\end{array}$ & $\begin{array}{c}\text { пероксидаза, } \\
\text { сек. }\end{array}$ & $\begin{array}{c}\text { каталаза, од. } \\
\mathrm{H}_{2} \mathrm{O}_{2}\end{array}$ & $\begin{array}{c}\text { пероксидаза, } \\
\text { сек. }\end{array}$ \\
\hline 2 міс. & $5,30 \pm 0,12$ & $60 \pm 1,22$ & $5,65 \pm 0,07$ & $57 \pm 2,22$ & $4,92 \pm 0,08$ & $64 \pm 1,22$ \\
\hline 4 міс. & $7,35 \pm 0,08$ & $43 \pm 1,49$ & $8,02 \pm 0,08$ & $41 \pm 1,79$ & $7,02 \pm 0,07$ & $49 \pm 1,79$ \\
\hline 6 міс. & $8,90 \pm 0,08$ & $24 \pm 1,23$ & $9,45 \pm 0,18$ & $22 \pm 1,23$ & $8,00 \pm 0,11$ & $28 \pm 1,59$ \\
\hline 8 міс. & $8,95 \pm 0,06$ & $27 \pm 1,09$ & $9,50 \pm 0,09$ & $24 \pm 1,48$ & $7,85 \pm 0,08$ & $32 \pm 1,29$ \\
\hline
\end{tabular}

Тенденція до зниження інтенсивності наростання активності з віком тварин відмічена і для пероксидази.

\section{Висновки:}

1. Встановлено, що найвищі показники кількості еритроцитів та вмісту гемоглобіну були у крові свиней за інтенсивної відгодівлі, не набагато нижчі у свиней в разі нормальної відгодівлі, а найнижчі у тварин у випадку зниженої годівлі. Причому у свинок у разі інтенсивної відгодівлі за досліджуваний період, кількість еритроцитів збільшилась на 17,93 \%, вміст гемоглобіну - на $10,08 \%$, то у свинок у разі годівлі за нормою відповідно на 18,8 та $12,82 \%$, а у свинок у випад-

\section{БІБЛІОГРАФІЯ}

1. Антипова Л. В. Методы исследования мяса и мясных продуктов / Л. В. Антипова, И. А. Глотова, И. А. Рогов. - М. : Колос, 2001. - 211 с.

2. Ветеринарна клінічна біохімія : навчальний посібник / [Мельничук Д. О., Мельничук С. Д., Грищенко В. А. та ін.]. - К., 2010. - 451 с.

3. Коваль О. А. Продуктивні та м'ясні якості свиней червоно-поясної спеціалізованої лінії при відгодівлі до різних вагових кондицій : автореф. дис. к.с.-г.н. : 06.02 .04 - технологія виробництва продуктів тваринництва. - Херсон, 2005. - 18 с.

4. Кондрахин И. П. Клиническая лабораторная диагностика в ветеринарии / И. П. Кондрахин, Н. В. Курилов, А. Т. Малахов. - М. : Агропромиз- ку зниженої годівлі - лише на 17,02 та 10 \% відповідно.

2. Найвищі показники активності каталази i пероксидази були вірогідно вищими у більш скороспілих свинок у випадку інтенсивного рівня годівлі. Найнижча ж активність ферментів крові спостерігалась у молодняка у разі зниженого рівня годівлі на $25 \%$.

3. Найвищим вміст кальцію та фосфору у сироватці крові за інтенсивної відгодівлі, дещо меншим він був у свиней у разі нормальної годівлі свиней і найменшим - у випадку годівлі на $25 \%$ нижче норми.

дат, 1985. -287 с.

5. Лабораторна діагностика у ветеринарній медицині : довідник / [Влізло В. В., Максимович I. А., Галяс В. Л., Леньо М. І.]. - Львів, 2008. - 112 с.

6. Лабораторні методи досліджень у біології, тваринництві та ветеринарній медицині : довідник / [Влізло В. В., Федорук Р. С., Ратич І. Б. та ін.] ; за ред. В. В. Влізла. - Львів : СПОЛОМ, 2012. $-764 \mathrm{c}$.

7. Плохинский Н. А. Руководство по биометрии для зоотехников / Н. А. Плохинский. - М. : Колос, 1969. - $256 \mathrm{c}$.

8. Попехина П. С. Кормление свиней / П. С. Попехина. - М. : Колос, 1967. - 208 с. 